\title{
Organizational Ethical Climate for Reduce Fraud Behavioral
}

\author{
Ida Ayu Putu Widani Sugianingrat ${ }^{1}$, I Wayan Suartina ${ }^{2}$, Sang Ayu Arie Indraswarawati ${ }^{3}$, Gusti Alit \\ Suputra $^{4}$ \\ \{widanidayu47@gmail.com¹, wynsuartina@gmail.com², arie.indraswarawati@gmail.com³ \\ alitsuputra150@yahoo.com ${ }^{4}$ \}
}

Universitas Hindu Indonesia, Denpasar, Bali, Indonesia ${ }^{1,2,3,4}$

\begin{abstract}
This study aims to examine and analyze the effect of organizational ethical climate and self awareness on fraud behavioral, and analyze the role of moderating self awareness on the influence of organizational ethical climate on fraud behavioral. The study was conducted on cooperatives in Bali, which numbered 4,151 units spread across 9 (nine) districts / cities. The number of samples used as research objects was determined by Slovin formula at a precision level of $10 \%$, so that the number of samples was 98 cooperative units. The determination of the cooperative which is the place of research is determined proportionally random sampling. The results showed that organizational ethical climate had a significant negative effect on behavioral fraud, whereas self awareness did not significantly influence behavioral fraud and also did not act as a moderating effect on organizational ethical climate on behavioral fraud. So in this study, it can be suggested that an ethical organizational climate plays a very important role in reducing the behavior of deviations that occur.
\end{abstract}

Keywords: organizational ethical climate, self awareness, fraud behavioral

\section{Introduction}

The cooperative institution is believed to be very in accordance with the culture and order of life of the Indonesian nation, because it contains the main meaning of cooperation for mutual interests (mutual cooperation). In its development, the system in cooperatives has management that helps. In reality there are deviations in the management of cooperatives, especially savings and loan cooperatives. This can hamper the development of cooperatives, so that it will affect the public trust in savings and loan cooperatives. Various problems that occur in cooperatives are not infrequently caused due to the management implemented running poorly, giving rise to various phenomena that we know such as fraud. States that fraud is a practice that can be done by people from inside and outside the organization, to gain benefits, both personal and group, which directly or indirectly, these actions can harm others [1].

In fact fraud can harm the company's finances. Fraud perpetrators are usually carried out by individual employees who work in an organization or company where he works, and even the perpetrators are from people whose task is to operate the operating system of the agency/company and also run an internal control system.

Some studies state that ethical behavior is an important function in organizational management [2]. Ethical behavior is important in a variety of life activities, although in some cases ethical deviations still occur. This needs to be rethought the efficiency of existing ethical strategies. Among them are still cases of fraud in various companies. Fraud is an interesting issue to study, because it is an unethical behavior in company activities

Based on observations, some of the possible causes of fraud are less ethical organizational environments and low individual awareness levels. Ethical behavior is behavior that is in accordance with social norms that are generally accepted in relation to right and good actions. This ethical behavior can determine the quality of individuals (employees) that are influenced by factors obtained from outside which then become the principles that are lived in the form of behavior

Based on the background described, the purpose of this study was to determine the role of organizational ethical climate and self-awareness in reducing fraud behavior in cooperatives in Bali. 


\section{Literature Review}

\subsection{Fraud Behavioral}

Lexical fraud behavioral means fraud / fraudulent behavior (English-Indonesian Dictionary). According to [3], fraud is any illegal act characterized by deception, concealment or violation of trust. Fraud is an intentional act involving fraud perpetrators who can harm others [4]. According to [5], Fraud can be termed fraud which implies a deviation and illegal act, which is done intentionally for certain purposes such as deceiving or misleading to other parties, which is done by people both from within and from outside the organization.

Fraud practices that often occur include misuse of interests, bribery, illegal acceptance and corruption [6]; [7]; [8]. Fraud is designed to exploit opportunities in an dishonest manner, which directly or indirectly harms others. Fraud can be interpreted as dishonest, corrupt, or unethical behavior. Fraud is an unethical act that is even considered very bad because it can have a negative impact not only for one individual but also for an organization or environment in which fraud is carried out [9].

[10] states fraud as a misinterpretation of the truth or concealment of material facts that causes a person to act adversely to another party. Fraud can occur either individually or in groups. This behavior can occur due to pressure, chance, and rationality. [11] describes the three causes in a chart shown in Figure 1, as follows:

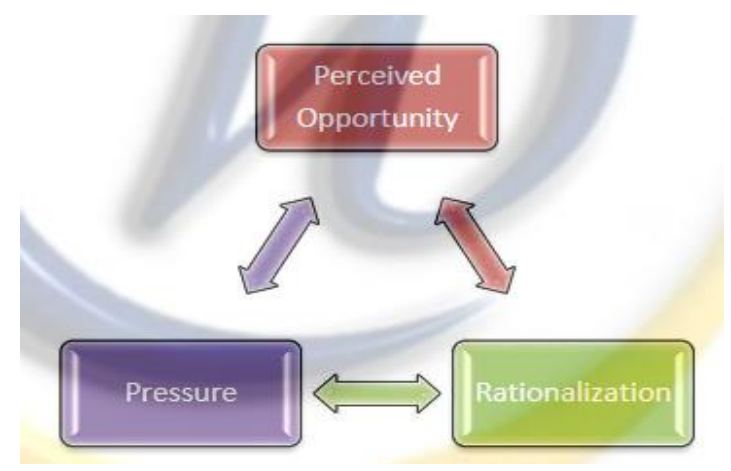

Figure 1. Causes of Fraud

Source: Priantara (2013:48)

Some research findings found that fraudulent behavior (fraud) can be caused by several factors such as a less ethical organizational climate (Organizational Ethical Climate), a person's low personal awareness (self awareness).

\subsection{Organizational Ethical Climate}

The first ethical climate theory was proposed by Victor and Cullen. This is a concept to understand the normative system of an organization. Organizations need to create an ethical situation / climate in order to avoid organizational members' behavior deviating from the prevailing rules [12]. Organizational Ethical Climate (organizational ethics climate) is defined as a normative system that guides organizational decision making and systemic responses to ethical dilemmas [13]. According to [14], states that an ethical climate is a work climate that reflects organizational procedures, policies, and practices with moral consequences. According to [15], organizational ethics climate is a psychological perception structure that focuses on ethical behavior of organizational members that are used to increase members' understanding of shared values to address and resolve ethical problems and awareness of personal responsibility.

The organizational ethical climate indicators refer to [16] which consists of egoism, benevolence, and principle. A better organizational ethics climate will minimize the occurrence of irregularities in the form of fraud and fraud. Research results show that organizational ethics cannot be separated from organizational life. [17] suggests that basically the dimensions and factors that influence organizational ethics originate from organizational life, including structure, individuals and the environment. 
The function of ethics in the organization develops not only on individual behavior at work. [18] explain the ethical climate in organizations influencing decision making. [19] say that organizational climate will develop human resources in healthy organizations. [13] in his research stated that climate influences the ethical behavior of individuals in business organizations. An ethical climate that develops in organizational life is social capital that will direct the behavior orientation of employees to work on the basis of ethics so as to avoid deviant behavior.

\subsection{Self Awareness}

According to [20] and [21] state that self awareness is an understanding of physical characteristics, personality, character, and temperament by recognizing the natural talents that they have and having a picture of a clear concept of oneself with all its strengths and weaknesses . [22], self-awareness is an embodiment of one's identity, can be referred to as a person who lives when the person in question is reflected in appearance, feeling of creativity and intention, value system, perspective, and behavior that he has. Self-awareness consists of two dimensions according to [23], namely personal self-awareness (private self awareness), and general self-awareness (public self awareness). Private self awareness is related to mood, perception, and feelings, while public self awareness is related to appearance and social action.

Increasingly improved awareness can reduce the possibility of fraudulent behavior, whereas an increasingly poorer level of awareness can reinforce fraudulent behavior. A number of studies have shown that a person with an improved level of awareness means cheating / deceiving behavior will diminish, including [24] and [25] found there is a negative influence between the effectiveness of selfawareness and fraudulent tendencies in the government sector. [26] shows that the effectiveness of internal self-control negatively affects the tendency of accounting fraud. So, with good self-awareness, it will minimize fraud committed by employees. But the lack of self-awareness will open opportunities for fraud.

\section{Framework for Research Concepts and Hypotheses \\ 3.1 Framework for Research}

Based on theoretical studies and supported by a number of research results, the research conceptual framework was constructed as shown in Figure 2, as follows:

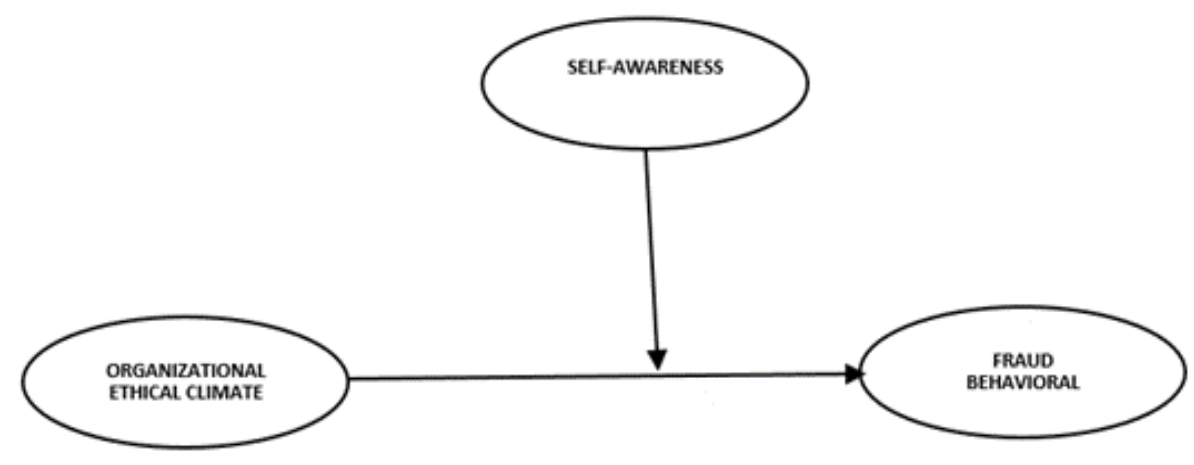

Figure 2. Research Concept Framework

\subsection{Hypotheses} as follows:

Referring to the conceptual framework as shown in Figure 2, the research hypothesis can be made

Hypothesis 1: Organizational ethical climate has a significant negative effect on fraud behavior Hypothesis 2: Self Awareness has a significant negative effect on fraud behavior 
Hypothesis 3: Self Awareness moderates the influence of Organizational ethical Climate on fraud behavior

\section{$4 \quad$ Research Methods}

\subsection{Location, Population, and Research Samples}

This research was conducted on cooperatives registered with the Cooperative Department in 2018 which numbered 4,151 cooperative units. The research sample was determined based on the Slovin formula with a precision level of $10 \%$, so that the number of samples was 98 units. The population distribution and sample of cooperatives in Bali are shown in Table 1.

Table 1. Population, and Research Samples

\begin{tabular}{clcc}
\hline \multirow{2}{*}{ No } & \multirow{2}{*}{ Regency/City } & \multicolumn{2}{c}{ Total } \\
\cline { 3 - 4 } & & Population & Samples \\
\hline 1 & Denpasar & 1,158 & 27 \\
\hline 3 & Buleleng & 206 & 7 \\
\hline 4 & Karangasem & 214 & 5 \\
\hline 5 & Bangli & 107 & 5 \\
\hline 6 & Glungkung & 1,018 & 3 \\
\hline 7 & Badung & 529 & 24 \\
\hline 8 & Tabanan & 413 & 12 \\
\hline 9 & Jembrana & 206 & 10 \\
\hline & & Total & $\mathbf{4 , 1 5 1}$ \\
\hline
\end{tabular}

Source: Depkop.go.id. 2018

\subsection{Research Data}

Data collection is done by interviewing cooperative leaders who are the research samples based on prepared questionnaires. The research data is in the form of a Likert perception scale with a range between 1 to 5. Answer 1 shows the perception of "very disagree", while 5 shows the perception of "strongly agree" to the statement contained in the questionnaire.

\subsection{Analytical Method}

Data that has been collected, then tabulated, then analyzed with the SmartPLS 3.0 program. The analysis was carried out in 3 (three) stages, namely: the stage of evaluation of the measurement model / outer model, the stage of evaluation of the structural / structural model / inner model, and the stage of testing the significance of the path.

Evaluation of the measurement model / outer model, including tests of validity and reliability through outer loading, Cronbach's Alpha and / composite reliability. Indicators can be said to be valid, if the value of outer loading is significant> 0.50, and is said to be reliable if Cronbach's Alpha and / composite reliability> 0.60. Evaluation of structural / structural model / inner model includes R-square (R2), Q-Square (Q2), and Goodness of Fit (GoF). Evaluation of testing the significance of the path (path) is based on a $5 \%$ error level, so that a path can be said to be significant if p-value $<0.05$ or t-statistic $>$ 1.96. 


\section{Results and Discussion}

\subsection{Characteristics of Respondents}

Table 2. Characteristics of Research Respondents by Gender, Age, Education Level, and Working Period

\begin{tabular}{llcc}
\hline \multirow{2}{*}{ Classification } & Frequency & Percentage \\
& & & \\
\hline \multirow{3}{*}{ Gender } & Men & 81 & 83,00 \\
& Women & 17 & 17,00 \\
\cline { 2 - 4 } & Total & 98 & 100,00 \\
\hline \multirow{3}{*}{ Age (Year) } & $21-32$ & 28 & 28,50 \\
& $33-44$ & 58 & 58,50 \\
& $45-56$ & 12 & 13,00 \\
\hline \multirow{3}{*}{ Level of Education } & Total & 98 & 100,00 \\
& Senior High School & 14 & 14,00 \\
& Bachelor & 84 & 100,00 \\
\cline { 2 - 4 } & Total & 98 & 10,00 \\
\multirow{3}{*}{ Working Period (Year) } & $1-5$ & 10 & 40,00 \\
& $6-10$ & 39 & 43,00 \\
& $11-15$ & 42 & 7,00 \\
\cline { 2 - 4 } & $16-20$ & 7 & 100,00 \\
\cline { 2 - 4 } & Total & 98 & \\
\hline
\end{tabular}

Source: Data processed, 2019

\subsection{Validity dan Reliabity}

The results of the SmartPLS analysis show the value of outer loading, cronbach's Alpha / Composite Reliability of each indicator in Table 3.

Table 3. Validity and Reliability Test Results

\begin{tabular}{|c|c|c|c|c|c|}
\hline No & Variable & Dimension & Indicator & Outer Loading & $\begin{array}{l}\text { Composite } \\
\text { Reliability }\end{array}$ \\
\hline \multirow{3}{*}{1} & \multirow{3}{*}{$\begin{array}{l}\text { Organizational ethical } \\
\text { climate }\end{array}$} & & Egoism & 0.699 & \multirow{3}{*}{0,766} \\
\hline & & & Benevolence & 0,698 & \\
\hline & & & Principle & 0,767 & \\
\hline \multirow{5}{*}{2} & \multirow{5}{*}{ Self Awareness } & & Mood & 0,901 & \multirow{5}{*}{0,904} \\
\hline & & Private Selt & Perception & 0,870 & \\
\hline & & Awareness & Feeling & 0,839 & \\
\hline & & Public Self & Appearance & 0,911 & \\
\hline & & Awareness & Action & 0,911 & \\
\hline \multirow{3}{*}{3} & \multirow{3}{*}{ Fraud Behavioral } & & Pressure & 0,694 & \multirow{3}{*}{0,712} \\
\hline & & & Chance & 0,682 & \\
\hline & & & Rationality & 0,642 & \\
\hline
\end{tabular}

\subsection{Accuracy of The Model}

\subsection{1 $\mathbf{R}$-Square $\left(\mathbf{R}^{2}\right)$}

The PLS analysis results show the influence of Organizational Ethical Climate and self awareness on fraud behavioral by 0.316 , meaning that $13.6 \%$ of fraud behaviors are influenced by organizational ethical climate and self awareness, the rest are other factors. That big influence is quite large.

\subsubsection{Discriminant Validity}

The results of discriminant validity analysis show the AVE root of each variable greater than the correlation between variables, as shown in table 4 . 
Table 4. Discriminant Validity

\begin{tabular}{llcccc}
\hline \multicolumn{1}{c}{ Variable } & AVE & $\sqrt{\text { AVE }}$ & OEC & SA & FB \\
\hline OEC & 0,522 & 0,722 & 1 & & \\
\hline SA & 0,596 & 0,772 & 0,588 & 1 & 1 \\
\hline FB & 0,552 & 0,743 & 0,553 & 0,407 & \\
\hline
\end{tabular}

The table shows where the root of AVE is greater than the value of the correlation between other variables, so all variables can be said to be discriminately valid.

\subsubsection{Goodness of Fit (GoF)}

Calculation of Goodness of Fit $(\mathrm{GoF})$ is done with the GoF formula $=\sqrt{ }(\mathrm{AVE} \times \mathrm{R} 2)$. The result is $\mathrm{GoF}=\sqrt{ }[(0,522+0,596+0,552) / 3 \times 0,316]=0,419$ (large). The results of fit model testing, both seen from the values of R2, discriminant validity, and GoF, show a large value, so it can be concluded that the model has a high level of accuracy.

\subsubsection{Evaluation of the significance of influences between variables}

Testing the influence between variables can be shown through Figure 3, and Table 5.

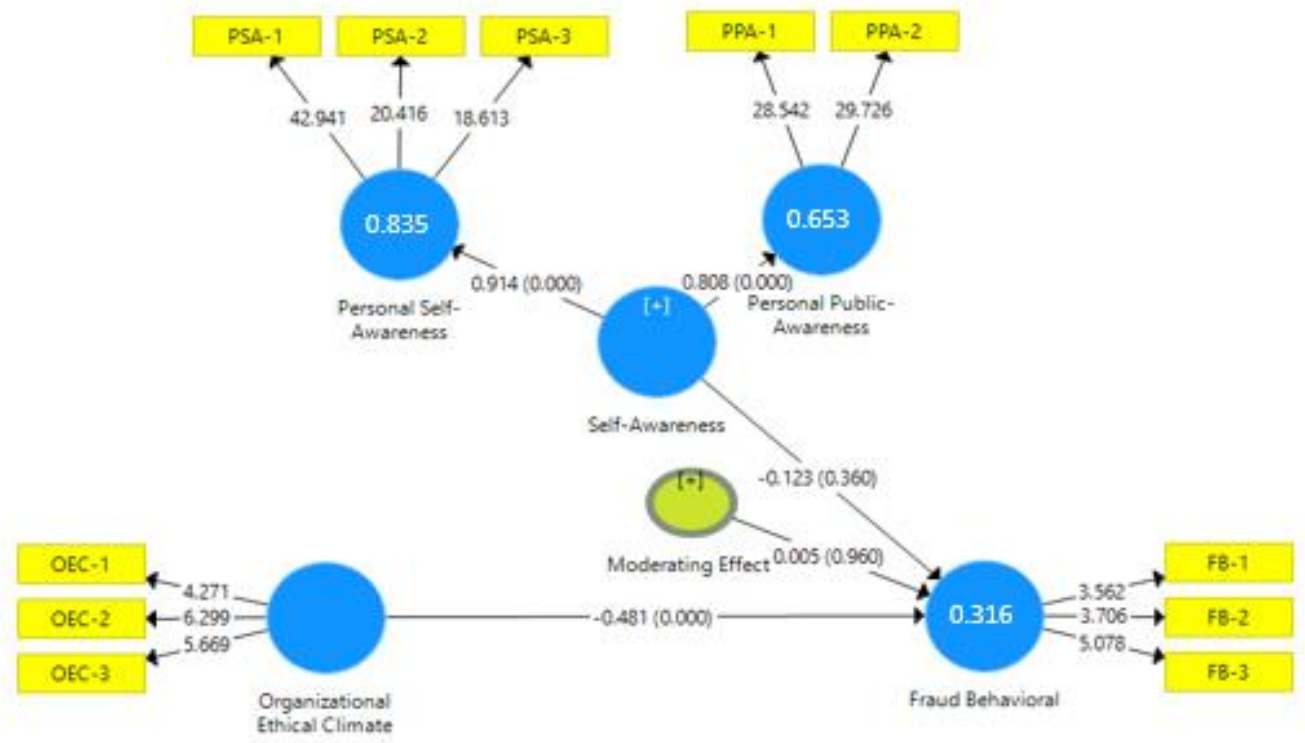

Figure 3. Processing results with Smart PLS

Table 5. Inter-variable Path Coefficients

\begin{tabular}{|c|c|c|c|c|c|c|}
\hline \multirow{2}{*}{ No } & \multicolumn{2}{|c|}{ Variables } & \multirow[b]{2}{*}{ Dependent } & \multirow{2}{*}{$\begin{array}{l}\text { Coeff. } \\
\text { path }\end{array}$} & \multirow{2}{*}{ p-value } & \multirow{2}{*}{ Info } \\
\hline & Independent & Moderation & & & & \\
\hline 1 & $\begin{array}{l}\text { Organizational } \\
\text { Ethical } \\
\text { Climate }\end{array}$ & & $\begin{array}{l}\text { Fraud } \\
\text { Behavioral }\end{array}$ & $-0,481$ & 0,000 & sig \\
\hline 2 & & Self-Awareness & $\begin{array}{l}\text { Fraud } \\
\text { Behavioral }\end{array}$ & $-0,123$ & 0,360 & Non sig \\
\hline 3 & $\begin{array}{l}\text { Organizational } \\
\text { Ethical } \\
\text { Climate }\end{array}$ & $\begin{array}{l}\text { Self- } \\
\text { Awareness }\end{array}$ & $\begin{array}{l}\text { Fraud } \\
\text { Behavioral }\end{array}$ & 0,005 & 0,960 & Non sig \\
\hline
\end{tabular}




\subsection{Discussion}

\subsubsection{Organizational ethical climate has a significant negative effect on fraud behavior}

The results of hypothesis testing indicate that the organizational ethical climate has a significant negative effect on fraud behavioral. This is indicated by the path coefficient value of -0.481 , with $\mathrm{P}$ Value $0.000<0.05$. These results give meaning that the real increase in organizational ethical climate can reduce fraud behavioral. These results can confirm a number of theories and the results of previous studies from [19] say that climate serves to develop human resources in healthy organizations.[13] stated that climate influences the ethical behavior of individuals in business organizations. [18] explain the ethical climate in organizations influencing decision making. An ethical climate that develops in organizational life is social capital that will direct the behavior orientation of employees to work on the basis of ethics so as to avoid deviant behavior. Every organization is responsible for trying to develop an organizational behavior that reflects honesty and ethics that is communicated in writing and can be used by all employees. The culture must have roots and have noble values that form the basis for the ethics of managing an organization or an entity [27].

\subsubsection{Self-awareness no significant negative effect on fraud behavior}

The results of hypothesis testing indicate that self awareness has a negative but not significant effect on fraud behavioral. This is indicated by the path coefficient value of $-0,123$, with P-Value $0,360>$ 0,05 . This result gives a meaning that an increase in self awareness can not significantly reduce fraud behavioral. These results are unable to confirm the results of the study, among others, by [28] which states overall ethical behavior in organizations, will be part of culture, then employees will accept the cultural aspects to be adopted, because culture is a system of assumptions that can have influence strong in directing the behavior and beliefs of followers. It can be explained that fraud behavior can occur even in conditions that have self-awareness but cannot be avoided, as well as due to opportunities and conditions that support. This condition can be described according to the fraud triangle theory which states that there are three factors that cause a person to commit fraud namely pressure, opportunity and rationalization.

\subsubsection{Self-awareness unable to moderate the influence of the Organizational ethical Climate towards fraud behavior}

The results of hypothesis testing indicate that Self-awareness has a non-significant negative influence on fraud behavior. This is indicated by the path coefficient value of -0.123 , with P-Value $0.360>$ 0.05 . These results mean that a real increase in self-awareness is not able to reduce fraud behavior. Thus, this result also illustrates that Self-awareness is not able to moderate the influence of the organization's ethical climate on fraud behavior. Statistically this is indicated by the path coefficient value of 0.005 with p-value $0.960>0.05$.

The results of this study are not fully in accordance with the opinion of [8], which states that efforts to prevent fraud can start from internal self-control. Fraud generally occurs because of pressure to commit fraud or an urge to take advantage of opportunities and justifications (generally accepted) from this action [29].

The reason for committing fraud cannot be entirely caused by social pressure and individual behavior. This result also contradicts [30] who argues that behavioral factors are at the root of the problem regarding fraud. A person's behavior in committing fraud is not solely due to the factors of self-awareness that influence it [31]; [32].

\section{Conclusions and Recommendations}

\subsection{Conclusions}

Referring to the results of the discussion, as already explained, it can be concluded as follows:

a. Organizational ethical climate has a significant negative effect on fraud behavioral. This means that a good ethical organizational climate can reduce fraud behavior in cooperative employees in Bali.

b. Self awareness has no significant negative effect on fraud behavioral. This means that good selfawareness can't reduce fraud behavior in cooperative employees in Bali.

c. Self awareness is not able to moderate the relationship between the organizational ethical climate to fraud behavioral significantly. This means that good self-awareness is unable to increase the 
influence of ethical organizational climate on decreasing fraudulent behavior in cooperative employees in Bali.

\subsection{Recommendations}

Based on the results of this study, several things can be suggested, namely:

a. In general, organizational ethics are good, but a number of factors need to be encouraged to be improved to become better, such as behavior, which is always trying to increase self motivation to achieve better goals. In addition to this, it can also be suggested to further enhance moral behavior or quality as a foundation of principles in a better direction.

b. Judging from the self-awareness factor, in general it is good, but several other things need to be considered to be improved, such as self-reflecting behavior in the sense that no one likes to be treated badly. Another thing, which is related to the need to increase perceptions / positive thoughts in realizing positive behavior as well.

\section{References}

[1]Comer, Michael J. (2003). Investigating Corporate Fraud. Aldershot, UK: Gower Publishing.

[2]Palomino, Pablo Ruiz, and Cañas, Ricardo Martínez. (2014). Ethical Culture, Ethical Intent, and Organizational Citizenship Behavior: The Moderating and Mediating Role of Person-Organization Fit. Journal of Business Ethics 120. Vol.1:pp. 95-108

[3]Tuanakotta, Theodorus M. (2013). Audit Berbasis ISA. Jakarta : Penerbit Salemba Empat.

[4]Johnstone, Karla M, Gramling, Audrey A. \& Rittenberg, Larry E. (2014). Auditing: A Risk-Based Approach to Conducting A Quality Audit. Ninth Edition. USA: South Western Cengange Learning.

[5]Karyono. (2013). Forensic Fraud. Yogyakarta.

[6]Bologna, J., Lindquist, R. J., \& Wells, J. T. (1993). The Accountant's Handbook of Fraud and Commercial Crime: Wiley New York, NY.

[7]Nugroho, R. S. (2015). Pengaruh implementasi sistem pengadaan secara elektrinik (E-Procurement) terhadap fraud pengadaan barang/jasa pemerintah (Studi pada Satuan Kerja Perangkat Daerah Kabupaten Magetan). Jurnal Administrasi Publik, Vol. 3, No.11, pp. 1905-1911.

[8]Tuanakotta, T. M. (2010). Audit forensik dan audit investigatif: Jakarta: Salemba Empat.

[9]Dinata, Ruri Octari, Irianto, Gugus \& Mulawarman, Aji Dedi. (2018). Menyingkap Budaya Penyebab Fraud: Studi Etnografi Di Badan Usaha Milik Negara. Jurnal Economia, Volume 14, Nomor 1.

[10]Garner, Bryan A. (2004). Black's Law Dictionary, 8thEdition. West Publishing CO. St. Paul, Minn.

[11]Priantara, Diaz. (2013). Fraud Auditing \& Investigation. Jakarta: Mitra Wancana Media.

[12] Gareth, R. J. (2007).Organizational Theory, Design And Change, Fifth Edition, Pearson Education, New Jersey.

[13]Duuh, M. (2010). Core Values, Cultureand Ethical Climate as Constitutional Elements of Ethical Behaviour: Exploring Differences Between Family and Non-Family Enterprises. Journal of Business Ethics, No. 97:pp. 473-489.

[14]Martin, Kelly D. \& Cullen, John B. (2006). Continuities and Extensions of Ethical Climate Theory: A Meta-Analytic Review. Journal of Business Ethics.

[15]Malloy D. C., J. Agarwal (2001). Ethical Climate in Nonprofit Organizations: Propositions and Implications. Nonprofit Management \& Leadership . Vol.12, No.1, pp. 39-54

[16]Keikoh, Ryu. (2017). Theoretical Research on Organizational Ethical Climate: Applications and Practices f Japanese Enterprises In China. Journal of Economic Behavior, Vol. 7, pp. 51-62.

[17]VanSandt, C, V. (2006). An Examination of the Relationship between Ethical Work Climate and Moral Awareness. Journal of Business Ethics, Vol. 68, No. 4, pp.409-432.

[18]Wyld, D, C \& Jones, C, A (2007) The Importance of Context: The Ethical Work Climate Construct and Models of Ethical Decision Making: An Agenda for Research. Journal of Business Ethics, Vol. 16, No. 4, pp.465-472.

[19]Sim R.,S \& Keons.T.,L (1997) Ethical Work Climate as a Factor in the Development of PersonOrganization Fit .Journal of Business Ethics, Vol. 16, No.11, pp.1095-1105.

[20]Gea, A. A. dkk. (2002). Relasi dengan Diri Sendiri. Jakarta: Elex Media Komputindo. 
[21]Mendatu, Achmanto. (2010). Parapsikologi: Sebuah pengantar singkat. Psikoeduka:Dipublikasikan bebas.

[22]Soedarsono, Soemarno. (2000). Penyemaian Jati Diri. Elek Media Komputindo, Jakarta.

[23]Brigham, J. C. (1991). Social Psychology. New York: Harper Collins Publisher.

[24]Pristiyanti, Ika Ruly. (2012). Persepsi Pegawai Instansi Pemerintah Mengenai Faktor-Faktor yang Mempengaruhi Fraud di Sektor Pemerintahan.Skripsi. Semarang : Fakultas Ekonomi UNNES.

[25]Fatun, Anik Najahningrum. (2013). Faktor-Faktor Yang Mempengaruhi Kecenderungan Kecurangan (Fraud): Persepsi Pegawai Dinas Provinsi DIY. Skripsi Akuntansi. Universitas Negeri Semarang.

[26]Wilopo. (2008). Pengaruh Pengendalian Internal Birokrasi Pemerintah dan Pelaku Tidak Etis Birokrasi terhadap Kecurangan Akuntansi di Pemerintah: Persepsi Auditor Badan Pemeriksa Keuangan. Jurnal Ventura, Vol 11, No. 1.

[27]Amrizal. (2004). Pencegahan dan Pendeteksian Kecurangan oleh Internal Auditor, (http://www.bpkp.go.id/unit/investigasi/cegah_deteksi.pdf, diunduh 20 Mei 2019).

[28]Sims, R. R., \& Sauser, W. I., Jr (Eds.). (2011). Experiences inteaching business ethics. Charlotte, NC: Information Age Publishing.

[29]Wibowo \& Wijaya, Winny. (2009). Pengaruh Penerapan Fraud Earlywarning System

(Fews)Terhadap Aktivitas Bisnis Perusahaan. Jurnal Informasi, Perpajakan, Akuntansi Dan Keuangan Publikvol. 4, No. 2. pp. 77 - 111.

[30]Ramamoorti, S. (2008). The psychology and sociology of fraud: Integrating the behavioral sciences component into fraud and forensic accounting curricula. Issues in Accounting Education, Vol. 23, No. 4, pp. 521-533.

[31]Bologne, J. (1993). Handbook on corporate fraud: Prevention, detection, and investigation: Butterworth-Heinemann.

[32]Dewani, R. A., \& Chariri, A. (2015). Money laundering dan keterlibatan wanita (Artis): Tantangan baru bagi auditor investigasi. Diponegoro Journal of Accounting, Vol.4, No.3, pp.1-6. 